\title{
Communication
}

\section{"Green Revolution and Redistribution of Rural Incomes: Pakistan's Experience" - A Comment}

\author{
MAHMOOD HASAN KHAN*
}

\begin{abstract}
"Green Revolution would indeed have exacerbated rural income inequalities if all that has been said so far accorded with the actual conditions prevailing in Pakistan. It will be shown in this paper that the majority of the above arguments are not correct, and that part of the evidence which has been used to demonstrate the adverse consequences of Green Revolution on income distribution is particularly untrustworthy. The paper also demonstrates that Green Revolution has been the most viable rural development strategy ever pursued in Pakistan." [4, pp.174-175]
\end{abstract}

\section{INTRODUCTION}

Considering the highly controversial nature of the impact of Green Revolution in Pakistan and the potential implications of its interpretations for public policy, it is imperative to clarify one's understanding of the central arguments and evidence in Ghaffar Chaudhry's recent article in the Pakistan Development Review [4]. Put it differently, how reliable is his evidence and how competent are his analytical tools in reaching what are essentially heroic but mostly erroneous conclusions on the effects of Green Revolution in Pakistan? Let me first make three general comments on the paper.

(1) Like many other researchers, Ghaffar Chaudhry concentrates on evidence from a few districts of the Punjab and generalises-for the country. This is particularly disturbing as these generalisations are about the impact of a phenomenon which has been evident largely in the Indus basin, which includes almost all of Sind but only the irrigated districts of the Punjab and excludes almost entirely the N.W.F.P. and Baluchistan.

(2) The author is demonstrably eclectic in using evidence (figures, data, etc.) for several aspects of Green Revolution. I suspect that some of the evidence, particularly unfavourable to his argument, was not available when he was writing his $\mathrm{Ph}$.D. thesis. However, since the article is apparently a revised version of the thesis, the author should have taken advantage of a number of studies, particularly on differences by farm size and tenure in allocation of inputs, land productivity and agrarian structure.

*The author is Professor of Economics in the Simon Fraser University, Canada. 
(3) I find it surprising that the author does not care to use even the elementary statistical methods in testing the "representativeness" of some of the averages he gives as evidence in support of a specific argument. Further, if you find the fire brigade wherever you see a fire, does it mean that the former is the cause of the latter? One has to fall back on a reasonable theory to verify an apparent cause-andeffect relationship.

\section{INTER-FARM INCOME DISPARITIES}

Let me turn to specific issues. The first issue is of inter-farm income disparities between "large" and "small" farms. Ghaffar Chaudhry maintains that small farmers have gained more than large farmers from Green Revolution [4, p.181]. What are his arguments and evidence? Let him speak for himself:

"In view of the higher use of inputs (both modern and traditional) and better managerial ability of the small family-farms, it seems natural to expect that small farms would be more productive than large farms. Similarly, the product-

ivity of the small farms may be expected to grow at a faster rate than that of large farms because of the more rapid increase in critical inputs of chemical fertilizer and irrigation water on small farms." [4, p. 178].

He hastens to add that these "assertions, however, remain to be verified by direct empirical evidence in Pakistan" [4, p.178]. Of course, he gives no direct evidence himself in the paper. He almost completely disregards considerable evidence to the contrary, particularly for "higher use of inputs (both modern and traditional) and better managerial ability of small family-farms". I shall presently draw attention to this evidence.

\section{Farm Productivity Differences}

Ghaffar Chaudhry's claims on the alleged "superiority" of small farms are, of course, based on highly speculative judgements as he admits. We have substantial direct evidence, not only from a few districts of the Punjab but from irrigated areas of Sind, that:

(a) small farmers were not the early adopters of the package of technology (water-seeds-fertilizer) associated with Green Revolution [2, Chapter 4;10;13;18] ;

(b) large farmers have had greater access to and have used more of (i) water, (ii) fertilizer, (iii) hired labour, and (v) machines (tractors), which are the so-called "new" inputs, mainly because of the lower cost of entry into bureaucratically-determined markets for these inputs and for institutional credit; where shortages of almost all inputs are endemic and the demand for them is evidently rising there develops a rationing system which favours the better-endowed individuals or groups $[7$, Chapter $3 ; 8 ; 10 ; 11 ; 12 ; 19 ; 20]$ (c) the more conclusive evidence of higher yield levels on small farms before Green Revolution has either weakened or disappeared since the late Sixties; the traditional strength of small farmer in his family labour and animal power has been clearly outstripped by the higher productivity effects of new inputs which larger farmers have been using in larger amounts or at higher levels $[11 ; 14 ; 18 ; 19]$.

Ghaffar Chaudhry's evidence for changes in productivity levels on small and large farms is based on data which he asserts are the "only data that allow productivity comparisons by farm size in Pakistan" [4, p.178], from Farm Accounts and Family Budgets of Cultivators in the Punjab (FAFB) [3]. There are two serious problems here. For one thing, why should the average gross and net incomes per acre be used as the only proxies for productivity? They can at best show that, given prices, levels of output per unit of land may be different on various sizes of farms. But they cannot help us to test the hypothesis that observed differences are related to farm size. Productivity (technical efficiency) of farm enterprises can be meaningfully analysed only by applying regression techniques. However, even if one accepts the argument that gross and net income levels per acre are reasonable measures of productivity, the author performs no statistical test to verify if the averages given in his Table 1 are representative. This brings me to my second point, that is the FAFB sample itself, as the author has used it as the only basis of evidence for some of his main arguments.

Ghaffar Chaudhry defines "small" and "large" farms as those with less than 12.5 acres and those with over 50.0 acres respectively [4, p.173]. However, the FAFB sample describes cultivators, for whom records are kept, as "big landowners", "peasant proprietors" and "tenants"[3]. It has three households in each of these tenurial categories in six districts of the Punjab, namely, Faisalabad, Sahiwal, Gujranwala, Mianwali, Rawalpindi, and Campbellpur $(3 \times 3 \times 6=54)$. The last two districts are classified as unirrigated (barani) and the others as irrigated. It should be noted, though, that sample farms in Mianwali are part irrigated and part unirrigated [3, Statistical Section, Table 1]. Of the 53 sample households-there is one missing observation in Faisalabad-35 are in irrigated and 18 in barani districts. Given the information on farm area of each holding (household) in FAFB reports for each year from 1965-66 to 1971-72, one can classify the sample into broad size-groups. As an example, I have done this for 1968-69 and 1970-71 in Table 1. These distributions reflect generally the picture for other years as well.

Using Ghaffar Chaudhry's definitions of small farms (less than 12.5 acres) and large farms (over 50.0 acres), I find that the FAFB sample has only 9 small farms (of which 6 are in irrigated and 3 in rainfed districts) and 3 large farms (of which one is in irrigated and 2 are in rainfed districts). These numbers are not different in other years. Surely the averages given by the author in Tables 1 and 3 would not be based on a sample of 9 small and 3 large farms! Or, was the sample size larger? If the answer is in affirmative, then obviously the author has not used his own definitions of small and large farms in the FAFB sample. 
Table 1

Distribution of Sample of Cultivators in FAFB, 1968-69 and 1970-71

\begin{tabular}{|c|c|c|c|c|c|c|c|c|c|}
\hline \multirow{2}{*}{$\begin{array}{l}\text { Farm Size } \\
\text { (acres) }\end{array}$} & \multicolumn{2}{|c|}{$\begin{array}{c}\text { Big } \\
\text { Landowners }\end{array}$} & \multicolumn{2}{|c|}{$\begin{array}{c}\text { Peasant } \\
\text { Proprietors }\end{array}$} & \multicolumn{2}{|c|}{ Tenants } & \multicolumn{2}{|c|}{$\begin{array}{l}\text { All Tenurial } \\
\text { Categories }\end{array}$} & \multirow{2}{*}{$\begin{array}{l}\text { All } \\
\text { Areas }\end{array}$} \\
\hline & I & B & I & B & I & B & I & B & \\
\hline
\end{tabular}

\begin{tabular}{lrrrrrrrrr}
\hline $1968-69$ & 0 & 0 & 0 & 0 & 0 & 0 & 0 & 0 & 0 \\
up to 7.5 & 0 & 0 & 3 & 0 & 3 & 3 & 6 & 3 & 9 \\
$>7.5-12.5$ & 3 & 1 & 6 & 6 & 7 & 2 & 16 & 9 & 25 \\
$>12.5-25.0$ & 8 & 3 & 2 & 0 & 2 & 1 & 12 & 4 & 16 \\
$>25.0-50.0$ & 1 & 1 & 0 & 0 & 0 & 0 & 1 & 1 & 2 \\
$>50.0-100.0$ & 0 & 1 & 0 & 0 & 0 & 0 & & 1 & 1 \\
$>100.0$ & 12 & 6 & 11 & 6 & 12 & 6 & 35 & 18 & 53 \\
All Sizes & & & & & & & & &
\end{tabular}

\section{0-71 and 1971-72}

up to 7.5

$>7.5-12.5$

$>12.5-25.0$

$>25.0-50.0$

$>50.0-100.0$

$>100.0$

All Sizes

Source: The Board of Economic Inquiry Punjab (Pakistan), Farm Accounts and Family Budgets of Cultivators in the Punjab, 1968-69, 1970-71, 1971-72, Statistical Section A, Tables III and VI.

Notes: 1. 'I' stands for irrigated districts and 'B' for unirrigated (barani) districts. There are six districts in the sample, namely, Faisalabad (Lyallpur), Sahiwal, Mianwali, Gujranwala, Rawalpindi, and Campbellpur (now named Attock). The first four districts are irrigated and the last two are barani. While the sample farms in Mianwali have part-irrigated and part-unirrigated area, it has been classified as irrigated.

2. Farms in the sample of FAFBs have been merely described by tenure as "big landowners", "peasant proprietors", and "tenants". There are in each district three families from each of these classes, except in Faisalabad where only two families are included in the peasant proprietor class. The sample size is, therefore, 53 and not $54(6 \times 3 \times 3)$.

\section{Changes in Distribution of Landholdings}

The second related issue on inter-farm income disparities is that of changes in the distribution of landholdings in the Sixties, between the 1960 and 1972 agricultural censuses. We know that control and use of land are based on the distribution of ownership and operational holdings. Ghaffar Chaudhry deals only with changes in the distribution of operational holdings. He asserts that access to land has become less concentrated in Pakistan: large farms have not exparided their area at the expense of small farms. He constructs land concentration indexes in Table 2 on the basis of data from the 1960 and 1972 agricultural censuses. A keen student of these censuses should know that their methodologies are very different. The two sets of data are not comparable without major adjustments in the 1960 census data. S. Akmal Hussain has recently done this in his study of the agrarian structure in the Punjab [7, Chapter 3;8]. These adjustments allow us to compare the 1960 and 1972 census data. The results then show that, at least for the Punjab and certainly in most of its irrigated districts, concentration of area increased at the upper end, while the number of very small farms increased without a proportionate increase in their share in total farm area. What we get from these figures is more, not less, concentrated access to land area in Pakistan, particularly in the Punjab. Studies on tractors have shown almost consistently a similar tendency for the large (tractor) farms to expand at the expense of small farms or tenants $[8 ; 13 ; 15 ; 21]$.

\section{CHANGES IN INCOMES OF LANDOWNERS AND LANDLESS TENANTS AND WORKERS}

Ghaffar Chaudhry argues that there has been a significant improvement in this relative (income) position of tenants during the Green Revolution period. He relies here solely on the FAFB sample data given in his Table 4. Now, if one cares to read the FAFB reports for each year from 1965-66 to 1970-71, about one-half of the so-called "big landowners" in the sample were using tenants for cultivation on a sharecropping (batai) basis; the other half were cultivating the land themselves. It is not clear if the average net incomes of big landowners using tenants exclude the share of their tenants. Can they really be compared with the averages for tenants and peasant proprietors? How consistent are all these figures? The other related aspect is that total income (gross or net) of each of the tenurial classes may differ simply because of changes in size of landholdings and sharing arrangements. Finally, the author provides no statistical test for the level of confidence in these averages as representative for each category. These questions create serious doubts about the validity of the author's optimism on tenants' improved position. On the contrary, we have some indication that the Green Revolution technology, supplemented more recently by increasing private profitability of tractors, has weakened the position of tenants vis-a-vis landlords $[7 ; 17]$. 
What about landless workers, their employment and wages? Here again we find limited evidence and highly speculative judgements on rapid expansion in rural employment and improved real rural wage rate. Ghaffar Chaudhry admits that we have no direct estimates of changes in rural employment in Pakistan. We do not even have an agreed estimate of the rate at which the labour force in agriculture was growing. Using his own dubious estimates of "job opportunities" and the U.N. estimates of growth of agricultural labour, the author concludes that the employment situation "consistently improved during the Sixties and Seventies" [4, p.185]. He clinches the argument with "visits to rural areas" and "conversations with officials of agricultural department". The estimates of growth of job opportunities (in Table 5) are based on an additive method. How can one calculate the interactive contribution of crop area, labour input and cropping pattern without using a production function approach which alone can help to estimate input demand elasticities for each factor. On the rate of growth of agricultural labour, the author accepts the U.N. estimates as reliable while he considers the estimated rates for total labour force "unbelievably high", although they both use the same data supplied by the government from the 1961 and 1972 population censuses [4, p.185].

The employment effects of tractors in Pakistan are somewhat confusing: the direct impact is evidently labour-displacing $[15 ; 19 ; 20 ; 21]$. The indirect positive effects of tubewell technology on employment, which the author stresses, may be true for the irrigated central and eastern districts of the Punjab, but that does not apply to other districts of the province and certainly not to Sind, N.W.F.P. and Baluchistan. Two additional comments on rural employment should be made here. First, the rate of migration of labour from rural to urban areas - reflected in the rapid growth of small towns into cities and even more rapid growth of large urban centres - increased rapidly during the Seventies. This reflects the expected higher returns on labour and job opportunities in industry and towns. Second, significant migration of labour from rural (and urban) areas of Pakistan to the Middle East started after $1972-73$, by which time Green Revolution had visibly abated.

On rural wages, we have only the author's word that the "greater demand for labour generated by Green Revolution must have exercised an upward pull on the average rural wage rate" [4, p.187]. I cannot argue with him on his evidence in Table 6 for changes in the average real rural wage because the sources of data and method of estimation are in the unpublished part of his $\mathrm{Ph}$.D. thesis. However, some other studies on changes in rural wage, particularly for the Green Revolution period, show no conclusive evidence. There is certainly no evidence pointing to a sustained increase in the real wage of agricultural workers in the Seventies $[12$, p. $213 ; 16$, pp. 180-181]. There was apparently some improvement in the real industrial wage in the late Sixties, but it was reversed in the early Seventies even though industrial employment kept on expanding $[5 ; 9]$.

\section{REGIONAL INCOME DIFFERENTIALS}

Admittedly, the issue of differences in incomes between various regions within one province and between provinces has not been much explored in the literature [16, Chapter 6]. On differences between the irrigated and rainfed areas, presumably in the Punjab only, Ghaffar Chaudhry elects to use gross value per acre as an appropriate index of crop productivity and suggests that this "may be a more relevant measure of income distribution changes" [4, p. 189]. "More relevant" than what? Even if the productivity differences shown in his Table 7 are accepted as valid proxies for changes in income distribution, I see no trend in the data indicating a narrowing of the gap in a consistent manner. At what statistical level of confidence is there a trend? I am also far from convinced that, even if there was a trend in the values of crop output per acre, it would not necessarily mean changes in the income gap between the irrigated and rainfed areas. Agricultural incomes depend on a host of other factors as well.

I have somewhat similar problems in understanding the data on provincial gross values of crop output in Table 8. What "various crops" have been included in the estimation of gross values? Then, even if one accepts the figures on their face value, in the context of Green Revolution the period of interest would be between 1964-65 and 1974-75. We know that Sind has been a major beneficiary of agricultural growth in this period, but the same confidence cannot be placed in figures about Baluchistan. The condition of the N.W.F.P. has certainly deteriorated [16, Chapter 10]. The author's claim on changes in the shares of various income groups in each province at the end of page 190 is like the bolt from the blue: how does he compute these figures? In studying aggregate averages of income, it should also be emphasized that they may conceal serious intraprovincial disparities, especially in provinces like the Punjab and Baluchistan. While Ghaffar Chaudhry may be right that there is no direct and precise evidence on increased income disparities between regions within one province and between provinces, his own evidence is far from complete and certainly not convincing.

\section{CHANGES IN INCOME SHARES OF RURAL HOUSEHOLDS}

Ghaffar Chaudhry's evidence for income shares of rural households in Table 9 is based on data from National Sample Surveys (NSS). On reading these figures closely, one cannot possibly reach the conclusion that income inequality among rural households has decreased. In fact, after 1966-67, the share of the lowest 10 percent fell slightly and almost no change occurred in the share of the highest 10 percent. The share of the lowest 20 percent did not change by much in the same period. Further, one hopes that the author appreciates that the Gini Coefficient is only one, and not the best, measure of income (asset) concentration. Values of this coefficient should be read with changes in the distribution of shares of various 
income (asset) groups. One could have a falling value of the Gini Coefficient without any idea of change in the actual distribution: two dissimilar Lorenz Curves (distributions) can yield the same value of this coefficient.

While we know little about the magnitude of changes in rural income distribution in Pakistan, the general impression about its direction is that it has not become less unequal in the last twenty years [6, pp.1272-1273]. We have also some evidence for rural income and poverty that inspires even less confidence in Ghaffar Chaudhry's assertion that "rural income inequalities in the late Sixties and early Seventies were considerably lower than those of the pre-Green Revolution period" [4, p.195]. Using the NSS data, Naseem and Alauddin have shown that rural income per person and per household declined during the 1963-1972 period [1, p. 446; 16, pp. 119-128]. A more serious development in the Sixties was the apparent increase in the absolute and relative shares of rural population below the "poverty line". The concept of poverty line is, of course, subject to various interpretations. However, in all approaches it is related to some measure of consumption. It should also be pointed out here that the author's claim about improved income distribution is not altogether consistent with evidence for changes in land concentration, growth patterns and productivity differences between farms by size and tenancy in the several studies I have cited in this note.

\section{CONCLUSION}

I have here focused on Ghaffar Chaudhry's basic arguments and evidence for the alleged positive efficiency and equity effects of Green Revolution in Pakistan. Many of his arguments are simply assertions, based on partial and even unrepresentative evidence or data. I have also drawn attention to serious flaws in some of his data and weaknesses in the method of interpretation. I find no overwhelming evidence or argument in the paper that the dissenting literature is "untrustworthy" or rhetorical. Much of this literature is agnostic and seriously questions the euphoria about the impact of the technocratic approach to agricultural growth associated with Green Revolution. The arguments may not always entirely be based on precise evidence, but they are reasonably grounded in logic and facts in demonstrating several disturbing features of the impact of new technology in rural areas of Pakistan.

\section{REFERENCES}

1. Alauddin, T. "Mass Poverty in Pakistan: A Further Study." Pakistan Development Review. Winter 1975.

${ }^{1}$ Naseem has raised serious doubt about the estimates of agricultural income shares obtained from the NSS data $[16, \mathrm{p} .118]$.
2. Berry, R.A., and W.R. Cline. Agrarian Structure and Productivity in Developing Countries. Baltimore, Maryland: Johns Hopkins University Press. 1979.

3. Board of Economic Inquiry Punjab (Pakistan). Farm Accounts and Family Budgets of Cultivators in the Punjab. Lahore. Publication Nos. 141 (1965-66), 146 (1966-67 and 1967-68), 149 (1968-69), 153 (1969-70), 154 (1970-71), $164(1971-72)$.

4. Chaudhry, M.G. "Green Revolution and Redistribution of Rural Incomes: Pakistan's Experience.” Pakistan Development Review. Autumn 1982.

5. Guisinger, S., and M. Irfan. "Real Wages of Industrial Workers in Pakistan: 1954 to 1970. "Pakistan Development Review. Winter 1974.

6. Guisinger, S., and N.L. Hicks. "Long-Term Trends in Income Distribution in Pakistan." World Development. Vol 11/12. 1978.

7. Hussain, S. Akmal. "The Impact of Agricultural Growth on the Agrarian Structure of Pakistan, with Special Reference to the Punjab Province: 1960 to 1978 "' Unpublished Ph.D. Dissertation, University of Sussex, 1980.

8. Hussain, S. Akmal. "Technical Change and Social Polarization in Rural Punjab." In Karamat Ali.(ed.) Pakistan: The Political Economy of Rural Development. Lahore: Vanguard Books. 1982.

9. Irfan, M. "Effects of Unionization, Product Market Concentration and Foreign Trade on Inter-Industry Wage Structure." Pakistan Development Review. Spring 1979.

10. Khan, M.H. The Economics of the Green Revolution in Pakistan. New York: Praeger Publishers. 1975.

11. Khan, M.H. "Farm Size and Productivity Relationships in Pakistan" Pakistan Development Review. Spring 1979.

12. Khan, M.H. Underdevelopment and Agrarian Structure in Pakistan. Boulder, Colorado: Westview Press. 1981.

13. Mahmood, Moazam. "The Pattern of Adoption of Green Revolution Technology and Its Effect on Land Holdings in the Punjab." Pakistan Economic and Social Review. 1/2. 1977.

14. Mahmood, Moazam, and Nadeem-ul-Haque, "Farm Size and Productivity Revisited." Pakistan Development Review. Summer 1981.

15. McInerney, J.P. and G.F. Donaldson, The Consequences of Farm Tractors in Pakistan. Washington, D.C.: World Bank. 1975. (World Bank Staff Working Paper No. 210)

16. Naseem, S.M. Underdevelopment, Poverty and Inequality in Pakistan. Lahore: Vanguard Books. 1981.

17. Salam, A. "Technical Change, Tenant Displacement and Adjustment in Pakistan." Pakistan Development Review. Winter 1977. 
18. Salam, A. "Factor Inputs Use and Factor Productivity on Different Farm Categories in the Punjab." Pakistan Development Review. Autumn 1978.

19. Salam, A. "Farm Tractorization, Fertilizer Use and Productivity of Mexican Wheat in Pakistan." Pakistan Development Review. Autumn 1981.

20. Sind Regional Plan Organisation. Agricultural Productivity Study:Statistical Report. Volumes 1 to 5. Karachi. 1978.

21. University of Karachi, Applied Economics Research Centre. Impact of Tractors on Agricultural Production in Pakistan: A Study for Agricultural Development Bank of Pakistan. Karachi. July 1982. 